University of Nebraska - Lincoln

DigitalCommons@University of Nebraska - Lincoln

U.S. National Park Service Publications and

Papers

National Park Service

2005

\title{
Short-Term Impacts of Military Overflights on Caribou During Calving Season
}

James P. Lawler

National Park Service

Audrey J. Magoun

Alaska Department of Fish and Game

C. Tom Seaton

Alaska Department of Fish and Game

Craig L. Gardner

Alaska Department of Fish and Game

Rodney D. Boertje

Alaska Department of Fish and Game

See next page for additional authors

Follow this and additional works at: https://digitalcommons.unl.edu/natlpark

Part of the Environmental Sciences Commons

Lawler, James P.; Magoun, Audrey J.; Seaton, C. Tom; Gardner, Craig L.; Boertje, Rodney D.; Ver Hoef, Jay M.; and Del Vecchio, Patricia A., "Short-Term Impacts of Military Overflights on Caribou During Calving Season" (2005). U.S. National Park Service Publications and Papers. 13.

https://digitalcommons.unl.edu/natlpark/13

This Article is brought to you for free and open access by the National Park Service at DigitalCommons@University of Nebraska - Lincoln. It has been accepted for inclusion in U.S. National Park Service Publications and Papers by an authorized administrator of DigitalCommons@University of Nebraska - Lincoln. 


\section{Authors}

James P. Lawler, Audrey J. Magoun, C. Tom Seaton, Craig L. Gardner, Rodney D. Boertje, Jay M. Ver Hoef, and Patricia A. Del Vecchio 


\section{SHORT-TERM IMPACTS OF MILITARY OVERFLIGHTS ON CARIBOU DURING CALVING SEASON}

JAMES P. LAWLER, ${ }^{1}$ National Park Service, 201 1st Avenue, Fairbanks, AK 99701, USA
AUDREY J. MAGOUN, ${ }^{2}$ Alaska Department of Fish and Game, 1300 College Road, Fairbanks, AK 99701-1599, USA
C. TOM SEATON, Alaska Department of Fish and Game, 1300 College Road, Fairbanks, AK 99701-1599, USA
CRAIG L. GARDNER, Alaska Department of Fish and Game, 1300 College Road, Fairbanks, AK 99701-1599, USA
RODNEY D. BOERTJE, Alaska Department of Fish and Game, 1300 College Road, Fairbanks, AK 99701-1599, USA
JAY M. VER HOEF, Alaska Department of Fish and Game, 1300 College Road, Fairbanks, AK 99701-1599, USA
PATRICIA A. DEL VECCHIO, Alaska Department of Fish and Game, 1300 College Road, Fairbanks, AK 99701-1599, USA

Abstract: The Fortymile Caribou Herd (FCH) is the most prominent caribou herd in interior Alaska. A large portion of the FCH calving and summer range lies beneath heavily used Military Operations Areas (MOA) that are important for flight training. We observed the behavior of Grant's cow caribou (Rangifer tarandus granti) and their calves before, during, and immediately following low-level military jet overflights. We also monitored movements of radiocollared cow caribou and survival of their calves. We conducted fieldwork from mid May through early June 2002. We concluded that military jet overflights did not cause deaths of caribou calves in the FCH during the calving period nor result in increased movements of cow-calf pairs over the 24-hour period following exposure to overflights. Short-term responses to overflights were generally mild in comparison to caribou reactions to predators or perceived predators. Caribou responses to overflights were variable, but responses were generally greater as slant distances decreased and jet speeds increased. A-10 jets caused less reaction than F-15s and F-16s. Although we found that short-term reactions of caribou to jet overflights were mild, we advise against assuming there are no long-term effects on calving caribou from jet overflights.

JOURNAL OF WILDLIFE MANAGEMENT 69(3):1133-1146; 2005

Key words: aircraft, Alaska, caribou, disturbance, jets, military, mitigation, noise, overflight, Rangifer tarandus.

No studies have definitively documented longterm population effects on caribou from military jet overflights. Harrington and Veitch (1992) reported that calf survival in woodland caribou was negatively correlated with level of exposure to military jets near Goose Bay, Labrador, and they suggested that jet overflights may compromise herd growth. On the other hand, Davis et al. (1985) concluded that caribou in the Delta Caribou Herd $(\mathrm{DCH})$ in Alaska were habituated to aircraft overflights, including military jets and civilian aircraft, and showed no evidence of long-term population effects from frequent aircraft activity.

Studies of aircraft overflights on caribou have addressed short-term effects of overflights, including acute responses at the time of the overflights and somewhat longer-term ( $<10$ days $)$ behavioral changes as a consequence of the overflights (Miller and Gunn 1979; Harrington and Veitch 1991, 1992; Murphy et al. 1993; Maier et al. 1998). Acute responses of caribou in the DCH exposed to military jet overflights were mild with $49 \%$ of caribou showing no overt behavioral response and only $13 \%$ moving in response to an overflight (Murphy et al. 1993). Exposure to jet overflights was correlated

1 E-mail: Jim_Lawler@nps.gov

2 Present address: 3680 Non Road, Fairbanks, AK 99709, USA. with shorter resting bouts in the postcalving and insect seasons and increased daily movements of caribou in the postcalving season (Murphy et al. 1993, Maier 1996, Maier et al. 1998). Harrington and Veitch (1992) and Harrington (2003) concluded that frequent overflights by low-level military jets can negatively affect calf survival. Most researchers studying the effects of aircraft overflights on caribou have suggested that female caribou with young calves are more reactive to aircraft overflights than caribou of other sex and age categories and that mitigation is particularly important in the calving and postcalving seasons (Miller and Gunn 1979, Harrington and Veitch 1991, Murphy et al. 1993, Maier et al. 1998). However, McCourt and Horstman (1974) found that caribou were more

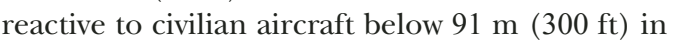
the postcalving winter and spring migration periods than they were during the calving season.

We examined the impacts of low-level military jet overflights on caribou during the calving season. Our objectives were to (1) document and model short-term responses of cow caribou during the calving season to low-level military jet aircraft in the Yukon MOAs, (2) evaluate caribou calf survival in relation to military jet overflights, (3) examine the effects of military jet aircraft on daily movements of cow caribou during the calving season, and (4) quantify sound levels produced by low- 
level military jet aircraft during directed overflights (Magoun et al. 2003).

The FCH is 1 of 5 international herds shared between Alaska and Yukon, Canada. Like other caribou herds in Alaska, the FCH has displayed major changes in abundance and distribution. In July 1994, a Fortymile Caribou Herd Management Planning Team was established to develop management and research plans to increase the herd size and reestablish the herd's historic range use in Alaska and the Yukon. Since initiation of the FCH management plan in 1996, the herd has increased about 4-13\% annually. Following the crossing of the Steese Highway in 2001 and the Yukon River in 2002, the herd began to use historic range not utilized for almost 40 years. There is broad support for continued conservative herd management to ensure herd growth and range expansion (Boertje and Gardner 2000).

\section{STUDY AREA}

The study area was in the Yukon-Tanana Uplands of eastern interior Alaska and included a portion of the 2002 core calving area of the FCH that was bounded on the north and south by latitudes $65^{\circ} 05^{\prime} \mathrm{N}$ and $64^{\circ} 45^{\prime} \mathrm{N}$, respectively, and to the east and west by longitudes $141^{\circ} 75^{\prime} \mathrm{W}$ and $143^{\circ} 85^{\prime} \mathrm{W}$, respectively (Fig. 1). Elevations range from $305 \mathrm{~m}$ to 2,000 $\mathrm{m}$ above sea level. Climate was semi-arid continental. At Circle, Alaska, the nearest location for which the National Weather Service has long-term weather data, mean annual precipitation from 1957 to 1997 was $20.9 \mathrm{~cm}$. Mean daily temperature ranged from $15.6^{\circ} \mathrm{C}$ in July to $-25^{\circ} \mathrm{C}$ in January. Topography was rolling forested areas interspersed with alpine tundra. The study area was within the subarctic boreal forest zone (Ducks Unlimited 1998). Dominant tree species included black spruce (Picea mariana) in low-lying areas and white spruce (Picea glauca), aspen (Populus tremuloides), and paper birch (Betula papyrifera) in better-drained locations (Swanson 1999). Above 1,000 m, tundra vegetation dominated. In general, caribou tended to occur in open vegetation types (e.g., tundra, subalpine, and sparsely treed areas at higher elevations).

The study area was overlain by MOAs. An MOA is a special-use airspace designated for nonhazardous military flight training activities. Mitigation measures within the MOA for the FCH were specific to the calving season and the calving grounds. When aggregations of calving caribou occurred east of longitude $143^{\circ} 45.00^{\prime} \mathrm{W}$, jets were to maintain an altitude of at least $610 \mathrm{~m}(2,000 \mathrm{ft})$ above ground level (AGL); west of this line, pilots were allowed to fly as low as $457 \mathrm{~m}(1,500 \mathrm{ft})$ AGL. For the majority of the year, U.S. military aircraft could fly subsonic as low as $152 \mathrm{~m} \mathrm{(500} \mathrm{ft)} \mathrm{AGL} \mathrm{in} \mathrm{this}$ area. Supersonic activity was authorized at or above 1,524 $\mathrm{m}(5,000 \mathrm{ft})$ AGL or 3,658 $\mathrm{m} \mathrm{(12,000}$ ft) mean sea level (MSL), whichever was higher (Department of the Air Force 1995).

\section{METHODS}

\section{Overflight Observations}

We had 2 field crews, each with 4-5 persons, and collected data on caribou behavior before, during, and after military jet overflights on the calving grounds of the FCH from 16 May to 5 June 2002. Each crew consisted of a biologist, 2 technicians, and 1 or 2 Third Air Support Operations Squadron (3rd ASOS) personnel to act as air controllers. A fixed-wing aircraft and a helicopter were available for support. On days when jet overflights were scheduled, pilot-biologist crews located concentrations of caribou by radiotracking collared cows and calves. These reconnaissance flights were done in the morning, usually between 0700 and $0800 \mathrm{hr}$. We were then transported by a Robinson- 44 helicopter to an observation site as close to a group of caribou as possible without disturbing it. The distance between the field crew and the caribou was variable depending on caribou location and terrain, and ranged between 50 and $2,000 \mathrm{~m}$, with most observations made between 300 and 1,000 m.

Once we were in place, we positioned a sound level meter (Larson Davis Model 812 sound level meter, Model 2560 microphone, and Model PRM826B preamp) at least $200 \mathrm{~m}$ away. Sound meters were programmed to record A-weighted sound exposure level (SEL) every second. The SEL is the total sound energy measured in a specific time period. A-weighting is a filter that adjusts sound level frequencies similarly to the human ear when exposed to low levels of sound and is most often used to evaluate environmental sounds. Our sound meter data were representative of the duration and variability of jet sound at the observation sites during the overflights but they are not representative of exact sound exposure experienced by caribou during the overflights because the monitoring equipment was usually closer to us than to the caribou. Because we could not anticipate caribou movements and because direction of overflights over caribou groups varied, the position of the sound meter relative to the jets, caribou, and observers varied.

Although we usually knew in advance what dates jets would be available to participate in the study, 


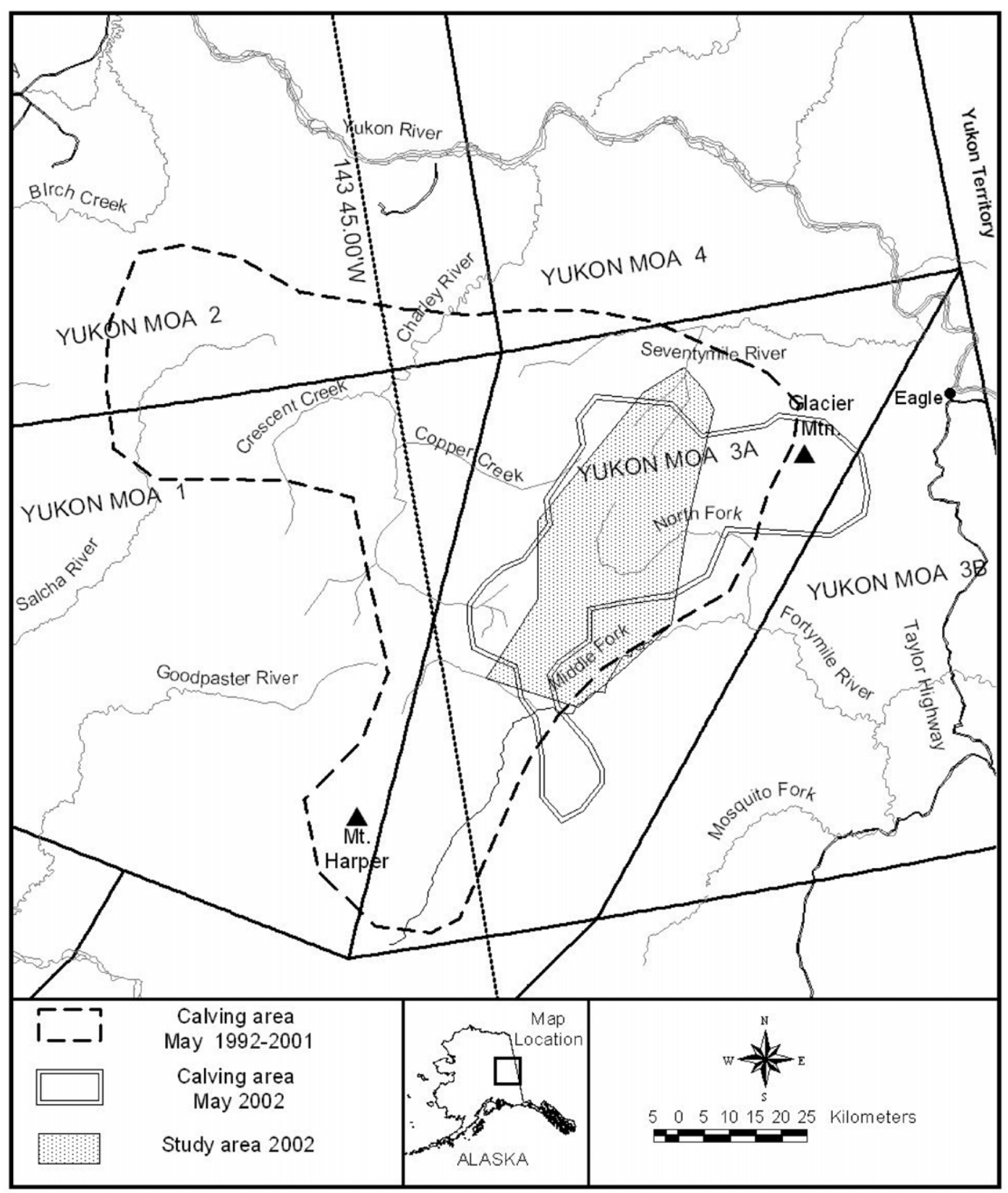

Fig. 1. Calving areas of the Fortymile caribou herd in the Yukon-Tanana Uplands, Alaska, USA, 1992-2002 and the study area for investigating the impacts of low-level military jet overflights on the Fortymile Caribou herd during calving.

we did not know arrival times because jets were dispatched to our observation sites only upon completion of their other missions. Jets (usually in pairs) arrived near the study area and pilots requested flight coordinates from ASOS personnel on the ground. Jets were then dispatched on a mission to fly over caribou. The air controllers directed jets to caribou groups we were observing and re- quested pilots fly at specified elevations and airspeeds. Pilots usually could not see the caribou; this frequently necessitated repeated attempts to position the jets over targeted caribou. Direction of passes and maneuvers during overflights were left to the discretion of pilots and air controllers, giving them the opportunity to use the overflights as training opportunities. Therefore, overflights tested 
Table 1. Sound characteristics of military jet missions used in the analysis of caribou reactions to jet overflights during the calving season of the Fortymile caribou herd, 16 May-5 Jun 2002.

\begin{tabular}{|c|c|c|c|c|c|c|c|c|c|c|c|}
\hline \multirow[b]{2}{*}{ Date } & \multirow[b]{2}{*}{ Jet } & \multirow{2}{*}{$\begin{array}{l}\text { Duration } \\
\text { of mission } \\
\text { (min) }\end{array}$} & \multirow{2}{*}{$\begin{array}{c}\text { No. } \\
\text { peaks }^{a}\end{array}$} & \multirow{2}{*}{$\begin{array}{c}\text { Mean time } \\
\text { between } \\
\text { peaks (sec) }\end{array}$} & \multirow{2}{*}{$\begin{array}{c}\text { Mean } \\
\text { width of } \\
\text { peaks }^{b}(\mathrm{sec})\end{array}$} & \multirow{2}{*}{$\begin{array}{c}\text { Highest } \\
\text { dBA }\end{array}$} & \multicolumn{5}{|c|}{ Number of peaks } \\
\hline & & & & & & & $60 s$ & $70 \mathrm{~s}$ & $80 s$ & $90 \mathrm{~s}$ & $100 \mathrm{~s}$ \\
\hline 16 May & $A-10$ & 24.5 & 10 & 77 & 78 & 99 & 1 & 3 & 1 & 5 & 0 \\
\hline 16 May & $A-10$ & 26.9 & 9 & 150 & 46 & 79 & 5 & 4 & 0 & 0 & 0 \\
\hline 16 May & $A-10$ & 31.4 & 16 & 72 & 50 & 96 & 5 & 4 & 5 & 2 & 0 \\
\hline 21 May & $A-10$ & 17.0 & 12 & 24 & 63 & 83 & 5 & 4 & 3 & 0 & 0 \\
\hline 21 May & $A-10$ & 17.0 & 8 & 67 & 69 & 86 & 2 & 4 & 2 & 0 & 0 \\
\hline 22 May & $A-10$ & 22.8 & 9 & 103 & 60 & 82 & 3 & 5 & 1 & 0 & 0 \\
\hline 23 May & $A-10$ & 1.6 & 2 & 35 & 30 & 86 & 0 & 1 & 1 & 0 & 0 \\
\hline 23 May & $A-10$ & 7.2 & 5 & 32 & 60 & 86 & 1 & 0 & 4 & 0 & 0 \\
\hline 28 May & $A-10$ & 10.3 & 8 & 39 & 43 & 87 & 5 & 1 & 2 & 0 & 0 \\
\hline 5 Jun & $A-10$ & 11.0 & 7 & 55 & 47 & 90 & 3 & 2 & 1 & 1 & 0 \\
\hline 5 Jun & $A-10$ & 32.7 & 15 & 81 & 55 & 94 & 4 & 4 & 3 & 4 & 0 \\
\hline 5 Jun & $A-10$ & 39.0 & 18 & 81 & 51 & 95 & 2 & 4 & 7 & 5 & 0 \\
\hline $\bar{x}$ & & 20.1 & 9.9 & 68.0 & 55.0 & 88.6 & & & & & \\
\hline
\end{tabular}

caribou reactions to realistic training scenarios in interior Alaska MOAs. We observed caribou reactions to military jet overflights by A-10, F-16, and F-15 aircraft. We asked pilots to avoid the study area when not participating in our research project.

We downloaded the sound data from the sound level meter into a computer, and we produced a graph of the change in sound level over time for each mission. Each mission produced a unique sound graph depending on the number and type of jets, relative position of the jets to each other, variability in speed and power settings, types of maneuvers, duration of the mission, terrain, and weather. We characterized each mission by type of jets, duration of the mission, number of sound level peaks, mean time between peaks, mean width of periods exceeding 59 decibels (dBA), highest $\mathrm{dBA}$, and number of peaks falling within each of 5 sound level categories (Table 1). We defined a peak as the point having the highest $\mathrm{dBA}$ once the sound level had reached at least $60 \mathrm{dBA}$ and before it fell again to $50 \mathrm{dBA}$. We present sound data primarily as an indication of potential sound levels experienced by caribou in interior Alaska MOAs.

We filmed caribou that we selected for overflights using digital movie cameras (Canon XL1 and Canon GL1). We focused a camera on an entire group or a portion of a group if the group was large and close to the camera. The number of caribou filmed during an overflight varied from a single cow-calf pair to $>50$ pairs. Whenever possible, we filmed groups for at least 2 hours before the jets arrived. Often, by the time the jets arrived, caribou groups had moved out of sight or into areas where they were difficult to observe, and we had to locate new groups $(75 \%$ of overflight events). In a few instances, we filmed groups for
$<5$ min before the jets arrived (19\% of overflight events). We continued filming after overflights for at least 15 minutes after normal behavior resumed or until groups disappeared from sight. We considered behavior normal if it involved common behaviors observed on the film preceding overflights such as: bedding (resting), feeding, walking, traveling (alternating walking and trotting but not feeding), and nursing. If more overflights were expected during the day, we continued filming in preparation for the next overflight. Although we sometimes filmed the same group through $>1$ mission, often the groups differed. We recorded weather, distance to caribou from the observation point, frequencies of radiocollared caribou that were in the group or nearby, and other incidental information such as presence and interactions with other wildlife.

\section{Calf Mortality}

As part of an ongoing study on mortality of caribou calves in the FCH, 52 caribou cows were radiocollared and calves of these cows, as well as approximately 25 calves without collared mothers, were radiocollared as close to birth as possible 13-27 May 2002. Radiocollars on calves contained mortality sensors and signals were monitored daily to determine if any calves died during the 24-hr period. We compared distances from the nearest jet overflights to locations of dead calves that died on the day of or the day after an overflight. We measured distances between location of calf deaths and the nearest overflights with a Geographic Information System (ArcView GIS 3.2, Environmental Systems Research Institute, Redlands, California, USA) in conjunction with an ArcView extension (Animal Movement Analyst; Hooge and Eichenlaub 2000). Mortality sites 
were visited and cause of death determined within a day of first hearing a mortality signal.

\section{Daily Movements in Relation to Overflights}

We tracked radiocollared cows daily from 11 May 2002 until they gave birth. We checked radio signals of 29 calves closest to our base of operations every morning from the time the calves were born until the end of the study to determine if they were still alive. We calculated daily distance moved by cow-calf pairs using ArcView GIS for days that we had consecutive-day locations; this distance was a minimum straight-line distance between the daily locations (Fig. 2).

When selecting groups of caribou for overflights, we tried to target groups that contained at least 1 radiocollared caribou. We were not able, however, to determine exact locations of most radiocollared cow-calf pairs at the time of the overflights. For this reason, we did not statistically analyze the relationship between daily distance moved by radiocollared cow-calf pairs and proximity to overflights, although we present raw data on this relationship. Because we knew the ages of the calves, we were able to examine the relationship between calf age and daily distance moved by cow-calf pairs.

\section{Short-term Reactions of Individual Caribou to Jet Overflights}

We defined an overflight event as any jet pass or series of passes near the target caribou that produced a peak sound level of at least $70 \mathrm{dBA}$ or, if $<70 \mathrm{dBA}$, an overflight that caused a detectable reaction by caribou. Only in 2 instances did we observe overflight events $<70$ dBA that caused detectable reactions, and in both cases, peak sound levels reached 65 dBA. During overflight events, we estimated slant angle and slant distance to caribou groups. The slant angle was the angle at which a jet passed the center of the group at the closest point, estimated from an imaginary horizontal plane where the caribou were standing. Slant distance was the straight- line distance from the jet to the center of the group at the closest point during the pass. We also recorded the speed of the jet at the time of the event; we obtained the speed from the jet pilot, or it was estimated by air controllers. Other information we recorded included direction of the jet passes, types of maneuvers the jets performed, and use of afterburners during the pass.

Using the videotapes recorded during overflight events, we transcribed reactions of caribou to the jets and stopped recording reactions of a given animal when it could no longer be individually identified on the tape (e.g., when it mixed with a number of other caribou or disappeared from sight). The same caribou may have been filmed on different days. We defined a caribou event as a particular caribou's reaction to a given overflight event on a given day.

We recorded caribou reactions at least 15 seconds before an overflight event began and until at least 15 seconds after the event ended, unless the caribou were no longer in view. We noted caribou behaviors recorded during events every $1-4$ seconds, depending on how rapidly behavior changed. It was not possible to determine exactly when a caribou first detected the jet or was exposed to peak sound during the event. Changes in the caribou's behavior, therefore, sometimes preceded or followed, by a few seconds, the exact moment when the jet appeared to pass the caribou at the closest point. Using a rule-based system, we ranked caribou reactions into 6 levels according to our subjective

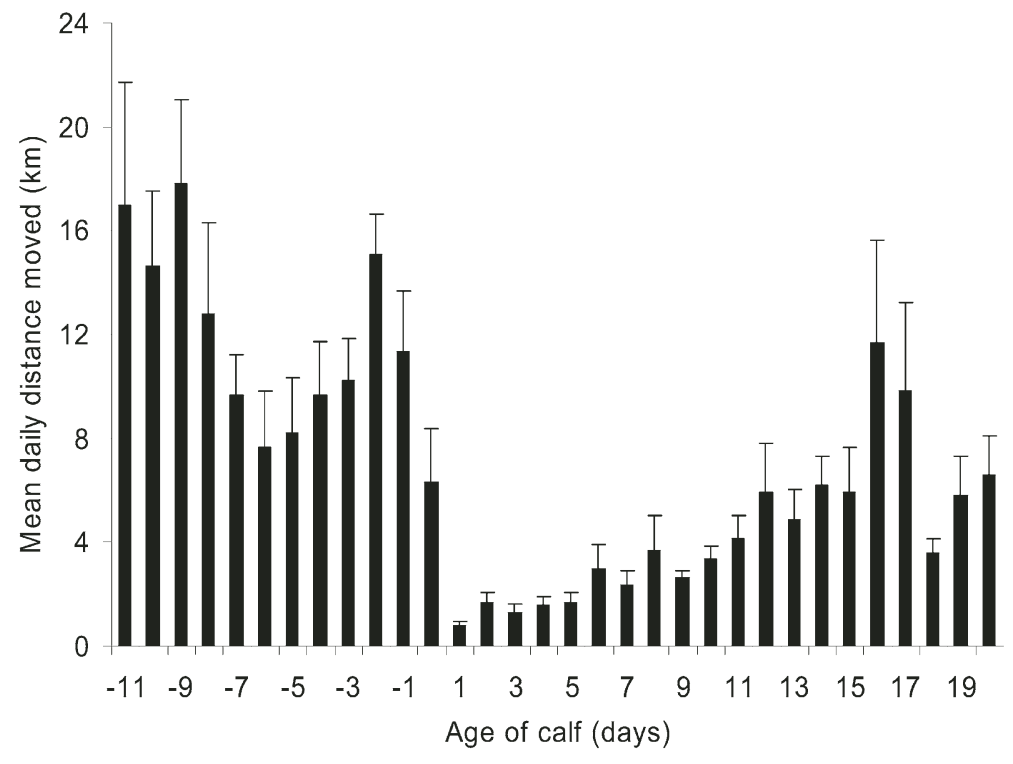

Fig. 2. Mean (+SE) straight-line daily distances moved by caribou-calf pairs in the Fortymile Caribou Herd in Alaska during the 2002 calving season. 
Table 2. Descriptions of reactions of caribou to military jet overflights on caribou in the Fortymile Caribou Herd during the calving season, 16 May-5 Jun 2002.

\begin{tabular}{|c|c|c|}
\hline \multicolumn{3}{|c|}{ Reaction } \\
\hline level & Description & Examples \\
\hline 1 & $\begin{array}{l}\text { No change in behavior detected during overflight or } \\
\text { mild change in behavior not obviously in response } \\
\text { to overflight }\end{array}$ & $\begin{array}{l}\text { Moving the head around; taking a few steps while feeding; } \\
\text { turning toward calf while nursing; stopping briefly while } \\
\text { walking or feeding. }\end{array}$ \\
\hline 2 & $\begin{array}{l}\text { Mild change in behavior that occurred temporarily } \\
\text { during overflight but did not involve an appreciable } \\
\text { increase in energy expenditure }\end{array}$ & $\begin{array}{l}\text { Lifting head while bedded, feeding, or walking; stopping to } \\
\text { stand with head up a few seconds; walking a few extra steps } \\
\text { while feeding; trotting for a few seconds while traveling } \\
\text { (traveling = alternating walking and trotting but no feeding). }\end{array}$ \\
\hline 3 & $\begin{array}{l}\text { Behavioral change from } 1 \text { activity to another with } \\
\text { only a mild increase in energy expenditure and no } \\
\text { obvious startle reaction }\end{array}$ & $\begin{array}{l}\text { Changing from feeding to standing or walking in response to } \\
\text { overflight; standing from bedding }>5 \mathrm{sec} \text { after jets passed } \\
\text { and then feeding; changing from walking to trotting as long } \\
\text { as trotting occurred before jets arrived. }\end{array}$ \\
\hline 4 & $\begin{array}{l}\text { Reactions involving a change in activity and move- } \\
\text { ment of the caribou's entire body in response } \\
\text { to overflight; does not involve trotting more than } \\
\text { a few seconds; a startle response that involved } \\
\text { movement of the entire body }\end{array}$ & $\begin{array}{l}\text { Startle reaction when jets passed and then resumption of } \\
\text { previous behavior; getting up slowly from a bedded position } \\
\text { after sound of jets had receded but within } 2-5 \text { sec of over- } \\
\text { flight; changing from walking to trotting at time of overflight } \\
\text { as long as trotting had not occurred before overflight and } \\
\text { did not continue for }>5 \mathrm{sec} \text {; a bedded or standing cow that } \\
\text { turned to touch its calf as the jet passed over as long as it } \\
\text { was not nursing at the time (this behavior while nursing is } \\
\text { common but is uncommon in other circumstances); standing } \\
\text { alert for }>5 \mathrm{sec} \text { while jets were in the vicinity regardless of } \\
\text { behavior before the overflight; changing from feeding to } \\
\text { standing or walking for }>5 \mathrm{sec} \text { without a startle reaction or } \\
\text { trotting for }<5 \mathrm{sec}\end{array}$ \\
\hline 5 & $\begin{array}{l}\text { Reactions that involved rising from bedded } \\
\text { position at the time of the overflight or startle } \\
\text { reaction while feeding or walking that ended in } \\
\text { trotting }\end{array}$ & $\begin{array}{l}\text { Rising slowly from bedded position just as jets passed over } \\
\text { and walking, standing, or feeding (if standing occurred, it } \\
\text { lasted }<5 \mathrm{sec} \text { ); changing from feeding to walking and trotting } \\
\text { with a startle or head up response as jets passed by } \\
\text { (trotting did not last }>5 \text { sec); jumping up from bedding, then } \\
\text { nursing or feeding }\end{array}$ \\
\hline 6 & $\begin{array}{l}\text { Reactions such as extended trotting or running; } \\
\text { startled jumps from bedded position followed by } \\
\text { alert standing, trotting, or running }\end{array}$ & $\begin{array}{l}\text { Jumping up from bedded position when jets passed by then } \\
\text { trotting or standing for }>5 \mathrm{sec} \text { and/or running; running even } \\
\text { briefly in response to overflight regardless of behavior before } \\
\text { overflight; trotting for }>5 \mathrm{sec} \text { in response to overflight if the } \\
\text { caribou had not been trotting before overflight and had not } \\
\text { resumed feeding for }>15 \mathrm{sec} \text { after overflight }\end{array}$ \\
\hline
\end{tabular}

determination of the relative amount of energy the activity required (Table 2; Fancy and White 1985, Fancy 1986) and whether the caribou appeared to be startled during the event. We categorized caribou responses before, during, and immediately following $(<15 \mathrm{sec})$ the overflight event.

\section{Group Response to Jet Overflights}

From videotapes, we analyzed overall group behavior of caribou before and after jet missions. We noted general behavior of the group (i.e., resting, feeding, or traveling) in the period ( $>1 \mathrm{hr}$ if possible) before the jets arrived as well as the behavior just before and after the mission. We also noted behavioral changes during a more extended period af- ter the mission (usually $>15$ min for groups that remained in view). If a combination of behaviors occurred in the group (e.g., bedding and feeding), then we listed the behavior of most animals in the group first (e.g., in the case above, most caribou were bedded). We examined if groups exposed to a series of longer and more intense missions reacted by changing their activity to 1 requiring more energy (e.g., changing from bedded to active or feeding to traveling). Length of a mission was from the time the jets arrived and produced at least $70 \mathrm{dBA}$ on the sound level meter or produced a detectable reaction until the last overflight when the sound level dropped below $50 \mathrm{dBA}$. We measured intensity of a mission by the number of peaks of at least 60 
$\mathrm{dBA}$ that occurred during the mission as well as the loudest peak that was recorded on the sound meter.

\section{Statistical Analysis}

We used a repeated measures model (PROC MIXED, SAS Version 8.02, SAS Institute, Cary, North Carolina, USA) to examine the influence of calf age (during the 3 weeks following birth) on the daily distance moved by cow-calf pairs $(n=$ 222). We log transformed daily distances moved prior to analysis.

We used logistic regression (PROC GENMOD, SAS Version 8.02, SAS Institute, Cary, North Carolina, USA) to examine the relationship of caribou reaction levels to overflight characteristics, specifically jet type (A-10, F-15, and F-16), speed (knots), slant distance (ft), slant angle, caribou group size, and a categorical variable $(v)$ for slant distance relative to $610 \mathrm{~m}(2,000 \mathrm{ft})$ AGL $(v=0$ if slant distance was $<610 \mathrm{~m}$ and $v=1$ otherwise). To check for overdispersion in our models, we used the Pearson chi-square value; in all cases, they were very close to 1 , indicating no evidence for overdispersion. We divided slant distance and speed by 1,000, and we divided slant angle and group size by 100 to appropriately scale these variables for inclusion in the models. Although we report distance and speed in meters and $\mathrm{km} / \mathrm{hr}$, respectively, we also report our findings in feet and knots. In interior Alaska MOAs, English units are used most often by the military to describe flight and mitigation parameters. Presentation of results in these units facilitates application of findings.

\section{RESULTS}

We observed 27 missions that usually involved 2 jets of the same type; 2 missions, however, involved mixed jet types when 2 sets of different types of jets arrived at the same time and alternated overflights on the target caribou. We recorded 179 overflight events for 890 different caribou events over 8 days. The maximum dBA we recorded was 114 , produced by an F-16 estimated to be $<91 \mathrm{~m}$ $(300 \mathrm{ft})$ from the sound meter. We did not record the speed of this aircraft because there were no caribou in view at the time. The same F-16 passing within $91 \mathrm{~m}(300 \mathrm{ft})$ of another sound meter at a speed of $880 \mathrm{~km} / \mathrm{hr}$ (475 knots) produced a dBA reading of 111 . The maximum $\mathrm{dBA}$ reading recorded for an F-15 was 113, when the jet was $<91$ $\mathrm{m}(300 \mathrm{ft})$ from the meter at a speed of 1,185 $\mathrm{km} / \mathrm{hr}$ (640 knots). For the A-10, the maximum dBA reading was 99 , when the jet passed the me-

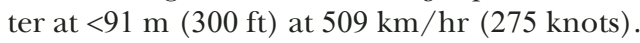

\section{Calving}

Calves were born 11-27 May 2002. The peak of calving (median calving date for radiocollared cows) occurred on 19 May. Most radiocollared calves (69\%) were born between 18 May and 23 May.

\section{Calf Mortality}

Of 65 radiocollared calves, 19 died during the study. Three died on a day with jet overflights, but death occurred before the overflights. Four calves died on the day following a day with overflights; 1 was 4 days old and died $20 \mathrm{~km}$ from where directed overflights occurred, 2 were 5 days old and died $12 \mathrm{~km}$ and $40 \mathrm{~km}$ from directed overflights, and the last was 10 days old and died $38 \mathrm{~km}$ from directed overflights. Because only directed overflights were to occur in the study area, we assume directed overflights were the only overflights the calves were exposed to within 24 $\mathrm{hr}$ of their deaths. The cause of death for these calves was predation; 2 were killed by wolves ( $\mathrm{Ca}$ nis lupus) and 1 each by a black bear (Ursus americana) and a grizzly bear (Ursus arctos). The remaining 12 calves died $>2$ days following a day when jets were in the study area. Their exposure to overflight events during the 8 days with overflight missions could not be determined because their locations in relation to directed overflights were not known.

\section{Daily Movements in Relation to Overflights}

No trend was evident in daily distance moved by cow caribou during the 10 days before they calved. Distance moved increased just before parturition and dropped sharply immediately following parturition (Fig. 2). Daily distance moved by cow-calf pairs increased as calves got older during the 3 weeks following birth $(F=85.04, P<0.001)$. The range of mean daily distances $( \pm s)$ moved by cows with calves that were 1 to 5 days old was from 0.8 $( \pm 0.20)$ to $1.7( \pm 0.40) \mathrm{km}$; for calves 6 to 10 days old, $2.3( \pm 0.57)$ to $3.7( \pm 1.36) \mathrm{km}$; and for calves 11 to 15 days old, $4.1( \pm 0.89)$ to $6.2( \pm 1.12) \mathrm{km}$. For calves 16-20 days old, mean daily distance moved was more variable and ranged from $3.6( \pm 0.57)$ to $11.6( \pm 3.94) \mathrm{km}$. Our study ended on 5 June, when the oldest calf in the radiocollared cow-calf pairs was 24 days old $(n=29)$.

\section{Short-term Reactions of Individual Caribou to Jet Overflights}

Logistic regression models examining the level of reaction in each caribou event found that group size, jet type, jet speed, slant angle, and 
Table 3. Results of logistic regression models ${ }^{a}$ showing the relationship of group size, jet type, jet speed, slant distance, and slant angle to the level of response by cow caribou in the Fortymile caribou herd to military jet overflights during the 2002 calving season.

\begin{tabular}{|c|c|c|c|c|c|c|c|c|c|c|}
\hline \multirow{3}{*}{$\begin{array}{l}\text { Independent } \\
\text { variables }\end{array}$} & \multicolumn{10}{|c|}{ Dependent variable $=$ reaction levels ${ }^{b}$} \\
\hline & \multicolumn{2}{|l|}{$>1$} & \multicolumn{2}{|c|}{$>2$} & \multicolumn{2}{|c|}{$>3$} & \multicolumn{2}{|l|}{$>4$} & \multicolumn{2}{|l|}{$>5$} \\
\hline & Coefficient & $\chi^{2}$ & Coefficient & $\chi^{2}$ & Coefficient & $\chi^{2}$ & Coefficient & $\chi^{2}$ & Coefficient & $\chi^{2}$ \\
\hline Intercept & $-2.444^{a}$ & 9.32 & $-2.8363^{a}$ & 11.68 & $-2.3227^{a}$ & 6.79 & -1.8222 & 2.19 & 0.0997 & 0.00 \\
\hline Group size ${ }^{c}$ & -0.0009 & 0.78 & 0.0011 & 1.00 & -0.0011 & 0.79 & -0.0022 & 1.72 & $-0.0097^{a}$ & 13.06 \\
\hline Jet $(A-10)$ & $0.9301^{a}$ & 7.14 & 0.2418 & 0.42 & -0.1944 & 0.24 & -1.0054 & 3.44 & $-3.0587^{a}$ & 14.48 \\
\hline Jet $(F-15)$ & -0.1974 & 0.71 & 0.1761 & 0.50 & -0.2730 & 1.11 & $-0.6309^{a}$ & 3.83 & $-1.1752^{\mathrm{a}}$ & 6.98 \\
\hline Jet $(F-16)$ & 0.000 & -- & 0.000 & -- & 0.000 & -- & 0.000 & -- & 0.000 & -- \\
\hline Speed (knots) ${ }^{d}$ & $7.8063^{a}$ & 24.36 & $6.4245^{a}$ & 16.34 & $5.8285^{a}$ & 11.81 & 3.1746 & 1.91 & 1.8202 & 0.32 \\
\hline e & $-1.8907^{a}$ & 57.02 & $-2.1630^{a}$ & 45.50 & $-2.5217^{a}$ & 44.04 & $-2.7856^{a}$ & 18.16 & -26.4917 & 0.00 \\
\hline$(1-\mathrm{v})^{*}$ slant distance $(\mathrm{ft})^{\mathrm{d}}$ & $-0.9397^{a}$ & 19.85 & $-0.7890^{a}$ & 10.52 & $-0.7865^{a}$ & 9.23 & -0.3801 & 1.19 & -0.9756 & 3.18 \\
\hline$(1-\mathrm{v})^{\star}$ slant angle $\mathrm{e}^{\mathrm{c}}$ & -0.1237 & 0.12 & -0.4815 & 1.45 & -0.6122 & 2.08 & $-1.4747^{a}$ & 5.58 & $-2.9287^{a}$ & 8.39 \\
\hline
\end{tabular}

slant distance all contributed significantly to models at $>1$ caribou reaction levels (Table 3 ). Group size had only a minimal effect (coefficient range of -0.0097 to 0.0011 ) and tended to be inversely correlated with reaction level. Slant angle had a larger effect (coefficient range of -0.6122 to -0.1237 ) than group size; the more directly overhead the jets were, the higher the probability that caribou would respond at a higher reaction level. Slant distance (coefficient range of -0.9756 to -0.3801 ), jet speed (coefficient range of 1.8202 to 7.8063 ), and jet type (coefficient range of -3.0587 to 0.9301 ) had substantial impacts on the reaction level of caribou (Table 3 ).

Of the 890 different caribou events, 169 (19\%) occurred at or above slant distances of $610 \mathrm{~m}$ $(2,000 \mathrm{ft}), 87(10 \%)$ from 457-609 m (1,500-1,999 $\mathrm{ft}), 133(15 \%)$ from $305-456 \mathrm{~m}(1,000-1,499 \mathrm{ft})$, 364 (41\%) from 152-304 m (500-999 ft), and 137 $(15 \%)$ below $152 \mathrm{~m}(500 \mathrm{ft})$. The shortest slant distance recorded was $30 \mathrm{~m}(100 \mathrm{ft})$ by an $\mathrm{A}-10$. The fastest speed recorded was $1,185 \mathrm{~km} / \mathrm{hr}(640$ knots) by an F-15. The fastest speed for an F-16 was $963 \mathrm{~km} / \mathrm{hr}(520$ knots $)$ and for an A-10, 648 $\mathrm{km} / \mathrm{hr}$ (350 knots).

At observed maximum jet speeds and minimum slant distances for each jet type, logistic regression models indicated that the probability of getting a reaction from a caribou $>$ level 1 was $75 \%$ for the A-10. The probability of getting a response progressively decreased with increasing response level (i.e., $40 \%$ at $>$ level 2 but only $8 \%$ at $>$ level 5 ; Fig. 3). A comparable analysis for the F-15 (Fig. 3) indicated that the probability of getting a reaction at $>$ level 1 to $>$ level 3 remained high ( $90 \%$ to $73 \%$, respectively), but it dropped considerably at reac- tions of $>$ level $4(38 \%)$ and $>$ level $5(47 \%)$. Unlike the A-10, for the F-15 at a low slant distance and high speed, the probability of getting higher-level reactions from caribou did not fall below $38 \%$. For the F-16 at low slant distance and high speed, the probability of getting higher-level reactions did not decrease over the range of possible reactions; the probability of a reaction at $>$ level 5 was only slightly less $(70 \%)$ than the probability of a reaction at $>$ level 1 (81\%; Fig. 3). Considering all jet types at slant distances $>610 \mathrm{~m}(2,000 \mathrm{ft})$ and minimum observed speeds, the probability of getting a reaction at $>$ level 3 was $<10 \%$.

Holding group size and slant angle constant (i.e., an overhead pass on a group of 30 caribou), we calculated the probability of getting higher-level caribou reactions (>level 3 ) and the probability of getting reactions at the highest level (reactions $>5$; Table 4). For the A-10 at $457 \mathrm{~m}(1,500 \mathrm{ft})$, there was $<10 \%$ chance of getting a reaction $>$ level 3 if jets maintained speeds of $444 \mathrm{~km} / \mathrm{hr}$ (240 knots). The results were quite different for the F-15 and F-16. At $457 \mathrm{~m}(1,500 \mathrm{ft})$, the probability of a >level 3 reaction at the slowest observed speeds was $19 \%$ for the F-15 and $24 \%$ for the F-16.

We did not detect any level 6 reactions (i.e., reactions that usually involved running or extended trotting) for any jet type when the slant distance was $>610 \mathrm{~m}(2,000 \mathrm{ft})$. The probability of getting a level 6 reaction from a caribou with an A-10 overflight was quite low; it was $<10 \%$ even at the most extreme flight parameters that we observed for this jet type $(30 \mathrm{~m}[100 \mathrm{ft}]$ and $648 \mathrm{~km} / \mathrm{hr}[350$ knots]). In contrast, even at $457 \mathrm{~m}(1,500 \mathrm{ft})$ and the slowest speeds, the probability of a level 6 reaction for the F-15 and F-16 was almost always 
$>15 \%$ (the only exception was the F-15 flying at $741 \mathrm{~km} / \mathrm{hr}$ [400 knots]), and the probability became much higher at the extreme flight parameters for these jet types (38-70\%; Table 4).

Individual caribou in the same group differed in their reactions to the same overflight, with some caribou reacting at lower levels (i.e., 1, 2, or 3 ) and others reacting at higher levels (i.e., 4, 5, or 6). Of 127 events in which we recorded reactions of $>1$ caribou, $42 \%$ of the events had mixed reactions (i.e., <level 4 and >level 4). Of those events with mixed reactions, $65 \%$ of the caribou reacted at lower levels and 35\% at higher levels. Mixed reactions were more common in larger groups. The mean group size for which we recorded mixed reactions to the same event was $92(n=$ 56), and for those without mixed reactions it was $33(n=72)$.

Distribution of reaction levels differed depending on whether caribou were bedded or active before the overflight (Table 5). Of 263 caribou events in which the caribou were bedded before the event, $75 \%$ of the caribou responded at level 1; of 627 caribou events in

which the caribou were active before the event, $40 \%$ responded at level 1 . Considering only data with slant distances of 305-456 m (1,000-1,499 ft), the proportion of higher-level reactions (i.e., levels 4,5 and 6) was 0.25 when animals were bedded before the overflight in comparison to 0.32
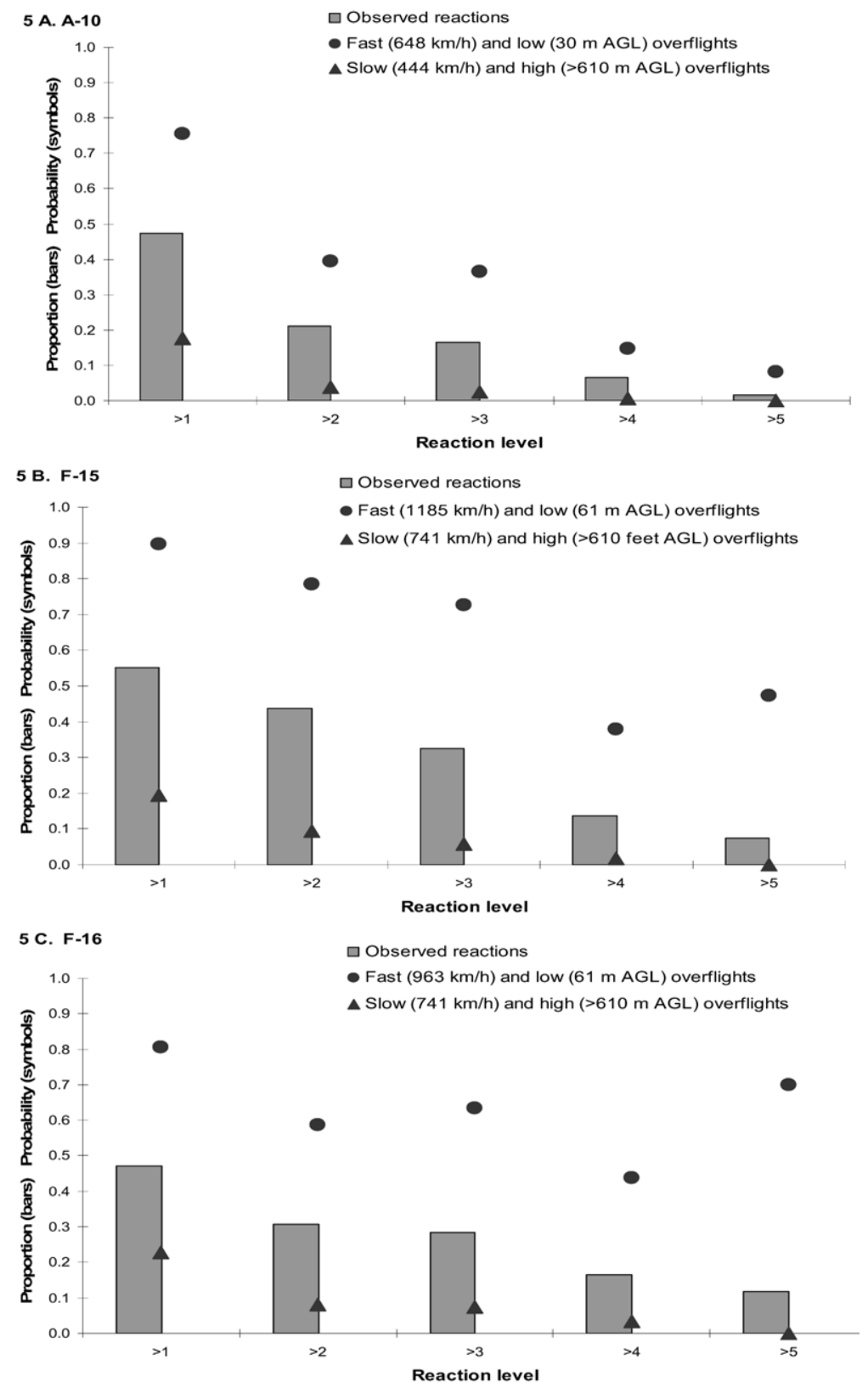

Fig. 3. Probability of caribou cows (assumed group size of 30 ) responding at increasingly higher reaction levels to overflights of military jets (A-10s, F-15s, F-16s) at observed maximum jet speed and minimum slant distance and at observed minimum jet speed and maximum slant distance. The fitted logistic regression model is given in Table 3 .

when animals were active prior to the overflight. At slant distances of 30-152 m (100-499 ft), the proportion of bedded caribou that reacted at higher reaction levels during an overflight was 0.16 in comparison to 0.32 when animals were active prior to the overflight. 


\section{Group Response to Jet Overflights}

Of 27 groups that were exposed to overflights, 13 changed from 1 behavior to another that required more energy, 10 remained the same, and 4 changed behavior to 1 that required less energy. For groups that increased energy output, mean duration of missions (19.2 min) and mean number of peaks per mission (8.9) were less than for those groups that remained the same or decreased energy output (21.6 min and 9.2 peaks, respectively). Considering occurred $<2 \mathrm{hr}$ apart), there was no evidence that duration of missions or number of peaks caused changes in behavior that required increased energy output; duration was 28.8 vs. 35.3 minutes for groups with increased output vs those without, respectively, and number of peaks was 12.8 vs. 15.2, respectively. Mean dBAs we recorded during the missions for both groups differed by only $0.5 \mathrm{dBAs}$. cumulative exposure (i.e., multiple missions that

\section{DISCUSSION}

We observed no abandonment of calves or panic responses that would lead to trampling of calves in response to overflights. Startle reactions and running that we observed in response to overflights lasted $\leq 15$ seconds in most instances. Longer bouts of caribou running that we observed appeared to be in response to terrestrial predators or perceived predators and were not related to overflights. Although calves sometimes engaged in bursts of play behavior that involved running at the time of an overflight (Miller and Gunn 1981), the duration of this behavior was similar to other spontaneous bouts of play that we observed when there were no overflights. By approximately 6 months after birth, $82 \%$ of the radiocollared calves that we knew had been overflown by military jet aircraft at distances $<2$ $\mathrm{km}$ were still alive. However, we do not know the total exposure or intensity of exposure for cow-calf pairs during the calving season.

Table 4. Probability of caribou in the Fortymile Caribou Herd reacting to overflights by A-10, $\mathrm{F}-15$, and $\mathrm{F}-16$ jets at levels $>3$ and $>5$ for different combinations of slant distances and jet speeds based on logistic regression models from data collected during the calving season, 2002.

\begin{tabular}{|c|c|c|c|c|c|c|c|}
\hline \multirow{2}{*}{$\begin{array}{c}\text { Jet } \\
\text { type }\end{array}$} & \multirow{2}{*}{$\begin{array}{c}\text { Reaction } \\
\text { level }\end{array}$} & \multirow{2}{*}{$\begin{array}{l}\text { Speed } \\
(\mathrm{km} / \mathrm{hr})\end{array}$} & \multicolumn{5}{|c|}{ Slant distance ${ }^{\mathrm{a}}(\mathrm{m})$} \\
\hline & & & 610 & 457 & 305 & 152 & 61 \\
\hline \multirow[t]{10}{*}{$A-10$} & $>3^{b}$ & 444 & 0.026 & 0.091 & 0.130 & 0.181 & 0.218 \\
\hline & & 500 & 0.030 & 0.107 & 0.151 & 0.208 & 0.250 \\
\hline & & 556 & 0.036 & 0.125 & 0.174 & 0.238 & 0.284 \\
\hline & & 611 & 0.042 & 0.145 & 0.201 & 0.271 & 0.321 \\
\hline & & 648 & 0.047 & 0.160 & 0.220 & 0.295 & 0.346 \\
\hline & $>5^{\mathrm{b}}$ & 444 & 0.000 & 0.018 & 0.029 & 0.047 & 0.062 \\
\hline & & 500 & 0.000 & 0.019 & 0.031 & 0.049 & 0.065 \\
\hline & & 556 & 0.000 & 0.020 & 0.033 & 0.052 & 0.068 \\
\hline & & 611 & 0.000 & 0.021 & 0.034 & 0.055 & 0.072 \\
\hline & & 648 & 0.000 & 0.022 & 0.036 & 0.057 & 0.074 \\
\hline \multirow[t]{5}{*}{$F-15$} & $>3 \mathrm{~B}$ & 741 & 0.058 & 0.191 & 0.259 & 0.341 & 0.396 \\
\hline & & 833 & 0.076 & 0.240 & 0.319 & 0.409 & 0.467 \\
\hline & & 926 & 0.099 & 0.297 & 0.385 & 0.481 & 0.540 \\
\hline & & 1,019 & 0.129 & 0.361 & 0.456 & 0.554 & 0.611 \\
\hline & & 1,111 & 0.165 & 0.431 & 0.529 & 0.624 & 0.678 \\
\hline \multirow[t]{7}{*}{$F-15$} & $>3^{b}$ & 1,185 & 0.200 & 0.489 & 0.586 & 0.677 & 0.726 \\
\hline & $>5^{b}$ & 741 & 0.000 & 0.140 & 0.210 & 0.302 & 0.367 \\
\hline & & 833 & 0.000 & 0.152 & 0.225 & 0.321 & 0.388 \\
\hline & & 926 & 0.000 & 0.164 & 0.242 & 0.342 & 0.410 \\
\hline & & 1,019 & 0.000 & 0.176 & 0.259 & 0.362 & 0.432 \\
\hline & & 1,111 & 0.000 & 0.190 & 0.277 & 0.384 & 0.455 \\
\hline & & 1,185 & 0.000 & 0.202 & 0.291 & 0.401 & 0.473 \\
\hline \multirow[t]{10}{*}{$F-16$} & $>3^{b}$ & 741 & 0.075 & 0.237 & 0.315 & 0.405 & 0.463 \\
\hline & & 796 & 0.088 & 0.270 & 0.354 & 0.448 & 0.506 \\
\hline & & 852 & 0.103 & 0.305 & 0.395 & 0.491 & 0.550 \\
\hline & & 907 & 0.120 & 0.344 & 0.437 & 0.535 & 0.593 \\
\hline & & 963 & 0.140 & 0.384 & 0.480 & 0.578 & 0.634 \\
\hline & $>5^{b}$ & 741 & 0.000 & 0.346 & 0.462 & 0.583 & 0.652 \\
\hline & & 796 & 0.000 & 0.358 & 0.476 & 0.597 & 0.665 \\
\hline & & 852 & 0.000 & 0.371 & 0.490 & 0.610 & 0.677 \\
\hline & & 907 & 0.000 & 0.384 & 0.503 & 0.623 & 0.689 \\
\hline & & 963 & 0.000 & 0.396 & 0.517 & 0.635 & 0.700 \\
\hline
\end{tabular}

a Straight-line distance from caribou to jet.

b Group size = 30; angle held constant at 0 (i.e., from vertical).
Harrington and Veitch (1992) concluded that calf survival of woodland caribou in a military jet training area near Goose Bay, Labrador, was negatively correlated with exposure to low-level jet overflights. Harrington (2003) suggested that close jet overflights in their study area could have led to lower calf survival due to increased caribou movement in a predator rich environment that resulted in increased exposure to predators. Harrington (2003) posited that woodland caribou would react to military overflights in a different manner than would Grant's caribou. Due to their evolutionary history, woodland caribou would tend to move away from a disturbance more than Grant's caribou would. We could not link overflight events to calf sur- 
Table 5. Distribution of caribou reaction levels relative to slant distances from military jets during the 2002 calving season of the Fortymile Caribou Herd, depending on whether the caribou were bedded or active at the beginning of overflights.

\begin{tabular}{|c|c|c|c|c|c|c|c|c|}
\hline & \multicolumn{2}{|c|}{$\begin{array}{l}\text { All slant } \\
\text { distances }\end{array}$} & \multicolumn{2}{|c|}{$<457 \mathrm{~m}$} & \multicolumn{2}{|c|}{$<305 \mathrm{~m}$} & \multicolumn{2}{|c|}{$<152 m$} \\
\hline & $n$ & $\mathrm{Pr}^{\mathrm{a}}$ & $n$ & $\mathrm{Pr}^{\mathrm{a}}$ & $n$ & $\mathrm{Pra}^{\mathrm{a}}$ & $n$ & $\mathrm{Pr}^{\mathrm{a}}$ \\
\hline \multicolumn{9}{|c|}{ Bedded to Active } \\
\hline Level 6 & 11 & 0.04 & 11 & 0.07 & 6 & 0.04 & 1 & 0.02 \\
\hline Level 5 & 19 & 0.07 & 13 & 0.08 & 13 & 0.09 & 1 & 0.02 \\
\hline Level 4 & 18 & 0.07 & 16 & 0.10 & 15 & 0.11 & 5 & 0.12 \\
\hline Level 3 & 5 & 0.02 & 2 & 0.01 & 2 & 0.01 & 1 & 0.02 \\
\hline Level 2 & 13 & 0.05 & 13 & 0.08 & 12 & 0.09 & 6 & 0.15 \\
\hline Level 1 & 197 & 0.75 & 106 & 0.66 & 89 & 0.65 & 27 & 0.66 \\
\hline Total & 263 & & 161 & & 137 & & 41 & \\
\hline \multicolumn{9}{|c|}{ Active to Active } \\
\hline Level 6 & 35 & 0.06 & 34 & 0.07 & 30 & 0.08 & 12 & 0.13 \\
\hline Level 5 & 29 & 0.05 & 26 & 0.06 & 19 & 0.05 & 6 & 0.06 \\
\hline Level 4 & 100 & 0.16 & 87 & 0.19 & 77 & 0.22 & 12 & 0.13 \\
\hline Level 3 & 54 & 0.09 & 46 & 0.10 & 36 & 0.10 & 2 & 0.02 \\
\hline Level 2 & 158 & 0.25 & 119 & 0.26 & 102 & 0.28 & 35 & 0.38 \\
\hline Level 1 & 251 & 0.40 & 154 & 0.33 & 94 & 0.26 & 26 & 0.28 \\
\hline Total & 627 & & 466 & & 358 & & 93 & \\
\hline
\end{tabular}

a Proportion of observations.

vival because we did not know the exposure of all of calves to overflight events.

Harrington and Veitch (1992) suggested that jet overflights in their study area could occur at levels where impacts on calf mortality interfered with population growth. However, the conclusions of Harrington and Veitch (1991) on the effects of jet overflights on caribou calf survival should not be extrapolated to other situations because their dataset had a number of apparent limitations including small sample size (i.e., 11 cow-calf pairs were followed during their 2-year study). In most cases, the authors did not directly observe jet overflights of cow-calf pairs during the calving and postcalving periods. Finally, the authors did not identify proximate causes of calf mortality or examine other factors that could have led to calf deaths (e.g., wolves and black bears were common in their study area).

We observed that the daily movement patterns of cow caribou just before and during the calving period were similar to those reported for parturient cow caribou in the Porcupine Caribou Herd (PCH), where military jet overflights do not occur (Griffith et al. 2002). Median straight-line daily distance for calves in the first week after birth was 1.3 and $2.5 \mathrm{~km}$ for FCH and PCH calves, respectively; in the second week, daily distance moved was 3.4 and $5.0 \mathrm{~km}$, respectively.

Daily distances moved by cow-calf pairs were significantly affected by calf age but we could not test the effects of overflight proximity on daily distance moved for most cow-calf pairs due to small sample size. Murphy et al. (1993) found that the loudest overflight of the day was a good predictor of daily distance moved by caribou during the postcalving period (6-17 Jun) in the DCH; however, they did not account for calf age. Moreover, they estimated SEL for an unreported proportion of the cow-calf pairs using a noise prediction program that required, among other variables, an estimate of slant range (i.e., slant distance), but they did not directly observe some of the pairs for which they estimated slant range. Murphy et al. (1993) acknowledge that slant ranges calculated for animals not observed (based on telemetry fixes) could have had poor temporal correspondence with overflights.

Murphy et al. (1993) concluded that a 10 dBA increase in maximum noise exposure for the day was associated with a $4.8 \mathrm{~km}$ increase in distance moved for postcalving caribou in the DCH. It is unlikely that this relationship applied to cow-calf pairs (at least in the first 2 weeks after birth) because an increase of $20 \mathrm{dBA}$ would mean an increase in daily movements of cow-calf pairs of 9.6 $\mathrm{km}$, and these are relatively large movements for cow-calf pairs in the 2-week period after birth. Movements of this magnitude occurred for only 10 of 213 daily distances we recorded; only 5 of these movements occurred within 24 hours after an overflight, and only 1 of these overflights occurred within $2 \mathrm{~km}$ of a cow-calf pair.

There were 16 instances when we documented overflights within $<2 \mathrm{~km}$ of radiocollared cow-calf pairs. Of the 16, 8 cow-calf pairs moved more than the mean for pairs with calves of that age in the 24 hours after the overflight, and 8 moved less. Of the 8 that moved more, only 1 moved $>4.8 \mathrm{~km}$ more than the mean distance for calves of that age. Of those that moved $<4.8 \mathrm{~km}$, the distance was only $1.9 \mathrm{~km}$ more than the mean. Maier et al. (1998), referring to the same study as Murphy et al. (1993), noted a small increase in movement during the postcalving period in response to jet overflights and concluded that the increased movement was of low energetic cost because of the generally low energetic costs of locomotion for caribou (Fancy and White 1987). However, any increase in movements by newborn calves potentially increases their exposure to predators (Harrington 2003). Murphy et al. (1993) and Maier et al. (1998) did not consider calf age in the analyses of their data. We found that age of calves was an important factor affecting the movements of 
cow-calf pairs during the calving period and was probably important in the postcalving period as well based on the pattern of movements for cow-calf pairs in the PCH (Griffith et al. 2002). Calf age should be considered when analyzing data on movements for cow-calf pairs, at least during calving and postcalving seasons.

We found that short-term behavioral responses to jet overflights were similar to those reported by other researchers (Harrington and Veitch 1991, Murphy et al. 1993). We avoided ranking responses as mild, moderate, and severe (McCourt and Horstman 1974, Miller and Gunn 1979) because these terms are subjective and imply an increasing stress level and greater physiological impacts. However, we are confident that reactions we observed at levels 1, 2, and 3 (i.e., lower-level responses) involved less energy and fewer startle responses than reactions at levels 4, 5, and 6 (i.e., higher-level responses).

Lower-level responses were distributed throughout the entire range of slant distances and jet speeds that we observed, but higher-level responses were much more common below $305 \mathrm{~m}$ $(1,000 \mathrm{ft})$ and occurred more commonly at higher speeds (Fig. 3). The slower-flying A-10 had less impact than the faster F-15 and F-16. The distribution of caribou reactions across the range of slant distances and speeds indicated that there was much individual variability in the way caribou reacted to jet overflights, but as jets got lower and speed increased, higher-level responses from caribou could be expected to occur more frequently.

Logistic regression models indicated that the level of caribou response to overflights was inversely related to group size; this is contrary to what other researchers have reported for caribou disturbed by turbo-helicopters (Miller and Gunn 1979) or fixed-wing aircraft (McCourt and Horstman 1974). We found that caribou in smaller groups were more likely to react at higher levels than caribou in larger groups, even though larger groups had a higher probability of having at least a small number of more reactive caribou.

We found that responses of caribou to jet overflights were mild compared to reactions in response to terrestrial predators or perceived predators that we observed. Similar to caribou in the DCH (Davis et al. 1985), caribou on the calving grounds of the FCH have had the opportunity to habituate to the presence of jets, and they usually showed little concern for the jets except when the jets were quite low and fast. Harrington and Veitch (1991) stated that caribou, regardless of habituation, will respond with a startle reflex when ex- posed to a sudden, intense noise such as low, fast military jets. While we generally agree with these authors, we found that not all caribou, even when they were in the same group, reacted with a startle response during such overflights.

Other researchers documented mild, short-term responses of caribou to military jet overflights and other types of aircraft disturbance, but they suggested that short-term responses potentially lead to long-term population consequences (Harrington and Veitch 1992, Maier 1996, Harrington 2003). However, no studies directly measured energetic or physiological costs to caribou from longterm exposure to jet overflights.

We found little evidence to suggest that groups of cow-calf pairs undertook movements away from areas where directed jet overflights occurred. Of the 13 groups that showed increased movement after overflights, it was not clear that the overflight events were the cause of the movements. We believe that other factors such as predators or perceived predators and behavior of a group before jets arrived affected group behavior during overflights. In 3 instances, caribou groups we observed running at the end of a mission; in 1 case, they may have been running from a grizzly bear that was chasing caribou before the mission. In another case, we suspected the caribou were disturbed by the observers just before the overflight. In the third case, we could not discern what made the caribou run because running continued on and off throughout the mission without obvious relationship to overflight events.

One of the most important factors affecting how a group of caribou reacts to jet overflights may be their activity and the duration of that activity before the jets arrive. Harrington and Veitch (1991) found that behavior prior to an overflight was significantly correlated with level of response by caribou. Caribou have cycles of rest and activity (Boertje 1985, Russell et al. 1993, Maier et al. 1998). When caribou reacted to jet overflights by changing activity, it was often not possible to tell if the change would have occurred even if the jets had not arrived, particularly without some indication of how long the caribou had been engaged in the activity before the jets arrived.

We observed that all caribou disturbed by jets at the beginning of a resting bout resumed resting after the jets left, usually within 20 minutes, even if they initially responded to overflights with activity. Likewise, caribou that had just begun feeding and were disturbed by jets, resumed feeding after the jets left. We suspect that jet overflights 
frequently ended resting or feeding bouts prematurely when overflights occurred at the end of a cycle. Maier et al. (1998) found that caribou exposed to jet overflights in the postcalving period in the DCH had a mean daily resting time that was less than that of caribou not exposed to overflights. Consequently, mean daily time active was greater, and most of the active time was spent feeding (Murphy et al. 1993). If daily resting times were reduced for caribou in our study, the reduced rest may be within the physiological tolerances for caribou given the low level of jet activity over the calving grounds and the current population growth rate of the FCH. However, appreciable increases in numbers, duration, and intensity of jet overflights, perhaps at the levels observed by Harrington and Veitch (1991) in Labrador, could conceivably cause detrimental interruptions in activity cycles and reductions in resting or feeding times, with biological consequences for the herd.

\section{MANAGEMENT IMPLICATIONS}

Our data indicate that A-10s could operate as low as $457 \mathrm{~m}(1,500 \mathrm{ft})$ AGL over calving caribou and cause $<$ level 3 behavioral responses if the jets maintain low speed and avoid maneuvers that require changes to higher power settings. Because the F-16 had a high probability of causing $>$ level 3 reactions in caribou at $457 \mathrm{~m}(1,500 \mathrm{ft})$ AGL, regardless of power settings, these jets should be restricted to elevations $>610 \mathrm{~m}(2,000 \mathrm{ft})$ AGL over the calving grounds if $>$ level 3 reactions are to be minimized during the calving period.

Under the FCH recovery plan and with the current mitigation levels for the calving period, the herd increased in numbers and expanded its range, suggesting that current mitigation levels are allowing for herd recovery under the environmental conditions and jet training exercises that have existed since the recovery began. Without more information on long-term impacts, and with the potential for increased military jet training in the Yukon MOAs, we advise caution in regards to relaxing the current mitigation measures for the FCH calving grounds.

Although we observed that short-term reactions of caribou to jet overflights were mild, we advise against assuming no long-term effects on calving caribou from jet overflights. Determining longterm effects of military jet aircraft on caribou will require long-term measurements of physiological responses, movements, and calf survival tied directly to sound exposure under realistic scenarios of military jet training. The technology for these types of studies are not adequately developed at this time, and the complexity and expense of such studies may be prohibitive.

\section{ACKNOWLEDGMENTS}

Funding and support for this project was provided by the U.S. Air Force (USAF) through the Eleventh Air Force Resource Protection Council and the committees for Resource Protection/Mitigation and Research and Monitoring. Field support was provided by the Alaska Department of Fish and Game and the National Park Service. We thank J. Hostman, USAF, who was instrumental in getting this project underway. We thank G. Rolf and the 611 th Air Operations Squadron for facilitating communication between biologists and the participating 3rd Wing, 168 Air Refueling Wing, and 354 Fighter Wing flying squadrons. This project would not have been possible without the participation of the USAF pilots who generously accommodated our overflight requests. Air control, often under difficult conditions, was provided by 3rd Air Support Operations Squadron personnel D. Aldrich, M. Batts, B. Grimm, S. Kurdziolek, T. Magdich, K. Parson, B. Peña, J. Pennington, E. Rankin, and A. Thweatt. We benefited while in the field from the efforts of biological technicians $\mathrm{T}$. Ball, D. Nigro, N. Pfeiffer, and pilots T. Cambier, A. Einer, M. Terwilliger, and P. Zaczkowski. We thank P. Valkenburg, D. James, L. Adams, R. Winfree, J. Maier, F. Harrington, and C. Smith for critical review of this manuscript.

\section{LITERATURE CITED}

BOERTJE, R. D. 1985. Seasonal activity of the Denali caribou herd, Alaska. Rangifer 5:32-42.

, AND C. L. GARDNER. 2000. The Fortymile caribou herd: novel proposed management and relevant biology, 1992-1997. Rangifer, Special Issue 12:17-38.

Davis, J. L., P. VAlkenburG, AND R. D. Boertje. 1985. Disturbance and the Delta caribou herd. Proceedings of the North American Caribou Workshop 1:2-6.

DEPARTMENT OF THE AIR FORCE. 1995. Final environmental impact statement, Alaska military operation areas. 11th Air Force, Elmendorf Air Force Base, Alaska, USA.

Ducks UnLimited. 1998. Yukon-Charley/Black River/40mile earth cover classification users guides. Ducks Unlimited project number AK-0024-22-002.

FANCY, S. G. 1986. Daily energy budgets of caribou: a simulation approach. Dissertation, University of Alaska, Fairbanks, USA.

, AND R. G. WHITE. 1985. Incremental cost of activity. Pages 143-159 in R. J. Hudson and R. G. White, editors. Bioenergetics of wild herbivores. CRC Press, Boca Raton, Florida, USA.

, AND - 1987. Energy expenditures for locomotion by barren-ground caribou. Canadian Journal of Zoology 65:122-128. 
Griffith, B., D. C. Douglas, N. E. Walsh, D. D. Young, R. McCabe, D. E. Russell, R. G. White, R. D. Cameron, And K. R. Whitten. 2002. The Porcupine caribou herd. Pages 8-37 in D. C. Douglas, P. E. Reynolds, and E. B. Rhode, editors. Arctic Refuge coastal plain terrestrial wildlife research summaries. U.S. Geological Survey, Biological Resources Division, Biological Science Report USGS/BRD/BSR-2002-0001.

Harrington, F. H. 2003. Caribou, military jets and noise: the interplay of behavioural ecology and evolutionary psychology. Rangifer, Special Issue 14:59-65.

, AND A. M. VEITCH. 1991. Short-term impacts of low-level jet fighter training on caribou in Labrador. Arctic 44:318-327.

- AND —. 1992. Calving success of woodland caribou exposed to low-level jet fighter overflights. Arctic 45:213-218.

Hooge, P. N., and B. Eichenlaub. 2000. Animal movement extension to ArcView. Version 2.0. Alaska Science Center-Biological Science Office, U.S. Geological Survey, Anchorage, Alaska, USA.

Magoun, A. J., J. P. LaWler, C. L. Gardner, R. D. Boertje, AND J. M. VER HOEF. 2003. Short-term impacts of military jet overflights on the Fortymile caribou herd during the calving season. Alaska Department of Fish and Game, Fairbanks, USA.

MAIER, J. A. K. 1996. Ecological and physiological aspects of caribou activity and responses to aircraft overflights. Dissertation, University of Alaska, Fairbanks, USA.
, S. M. Murphy, R. G. White, And M. D. Smith. 1998. Responses of caribou to overflights by low-altitude jet aircraft. Journal of Wildlife Management 62:752-766.

McCourT, K., AND L. Horstman. 1974. The reaction of barren-ground caribou to aircraft. Pages 1-36 in R. D. Jakimchuk, editor. The reaction of some mammals to aircraft and compressor station noise disturbance. Biological Report Series, Volume 23. Renewable Resources Consulting Service, Canadian Arctic Gas Study.

Miller, F. L., AND A. GunN. 1979. Responses of Peary caribou and muskoxen to helicopter harassment. Canadian Wildlife Service Occasional Paper 40, Ottawa, Ontario, Canada.

— AND — 1981. Play by Peary caribou calves before, during, and after helicopter harassment. Canadian Journal of Zoology 59:823-827.

Murphy, S. M., M. D. Smith, R. G. White, J. A. Kitchens, B. A. Kugler, And D. S. Barber. 1993. Behavioral responses of caribou to low-altitude jet aircraft. U.S. Air Force Technical Report AL/OE-TR-1994-0117.

Russel, D. E., A. M. Martell, And W. A. C. Nixon. 1993. Range ecology of the Porcupine caribou herd, Canada. Rangifer, Special Issue 8.

Swanson, D. K. 1999. Ecological units of Yukon-Charley Rivers National Preserve, Alaska. National Park Service report YUCH-99-001. National Park Service, Fairbanks, Alaska, USA.

Associate Editor: McCorquodale. 